JURNAL PENDIDIKAN, p-ISSN 2715-095X, e-ISSN 2686-5041

Volume 29, No.2, Juli 2020 (93-100)

Online: http://journal. univetbantara. ac. id/index. php/jp

\title{
Media Pembelajaran Multimedia Interaktif untuk Anak Tunagrahita Ringan
}

\author{
Farah Nayla Maulidiyah \\ Jurusan Teknologi Pendidikan, Fakultas Ilmu Pendidikan, Universitas Negeri Malang, \\ Email: farahnayla10@gmail.com
}

\begin{abstract}
Abstrak: Tujuan penelitian ini adalah mengetahui kelayakan dan pengaruh penerapan media pembelajaran multimedia interaktif sebagai bahan ajar siswa tunagrahita ringan.. Paper ini merupakan hasil telaah dari artikel-artikel sebelumnya yang terkait dengan anak tunagrahita ringan,. Paper ini ditulis untuk mengetahui pengaruh pembelajaran berbantuan media multimedia interaktif terhadap kemampuan motorik, berbentuk video dan adobe flash terdahap motivasi belajar siswa tunagrahita ringan
\end{abstract}

Kata-kata Kunci: pengaruh, multimedia interaktif, pembelajaran, tunagrahita ringan

\section{Interactive Multimedia Learning Media for Children with Light Developmental Disabilities}

\author{
Farah Nayla Maulidiyah \\ Jurusan Teknologi Pendidikan, Fakultas Ilmu Pendidikan, Universitas Negeri Malang, \\ Email:farahnayla10@gmail.com
}

\begin{abstract}
The purpose of this study is to determine the feasibility and influence of the application of interactive multimedia learning media as teaching material for mild retarded students. This paper is the result of a review of previous articles related to mild retarded children.. This paper was written to find out the effect of learning assisted by interactive multimedia media on motor skills, in the form of video and Adobe Flash with the learning motivation of students with mild mental retardation
\end{abstract}

Key Words: influence, interactive multimedia, learning, mild retardation

\section{Pendahuluan}

Undang-Undang Nomor 20 Tahun 2003 tentang Sistem Pendidikan Nasional Pasal 32 disebutkan bahwa: "pendidikan khusus (pendidikan luar biasa) merupakan pendidikan bagi peserta didik yang memiliki tingkat kesulitan dalam mengikuti proses pembelajaran karena kelainan fisik, emosional, mental, sosial". Selanjutnya PP No. 17 Tahun 2010 Pasal 129 ayat (3) menetapkan bahwa peserta didik berkelainan terdiri ataspeserta didik yang: tunanetra, tunarungu,tunawicara, tunagrahita, tunadaksa, tunalaras, berkesulitan belajar, lamban belajar, autis, memiliki gangguan motorik, menjadi korban penyalahgunaan narkotika, obat terlarang dan zat adiktif lain serta memiliki kelainan lain. Pada dasarnya pendidikan adalah hal yang harus ditempuh oleh semua kalangan manusia, baik manusia 
normal atau yang berkebutuhan khusus.ABK (anak berkebutuhan khusus) memiliki hambatan dan kendala dalam pendidikan di sekolah maupun kehidupan sehari-hari di masyarakat. Ada beberapa jenis anak berkebutuhan khusus, diantaranya adalah anak tunagrahita. Kemis \& Ati (2013:1) tunagrahita adalah individu yang secara signifikan memiliki inteligensi di bawah 70 berdasarkan skala Wechsler Intelligence Scalefor Children (WISC).

Tuna grahita terbagi terbagi menjadi 3 kategori, yaitu ringan, sedang dan berat. Tunagrahita ringan (IQ 50-70) yaitu mereka yang termasuk kedalam kelompok yang kecerdasan dan adaptasi sosialnya terhambat, namun mereka mempunyai kemampuan untuk berkembang dalam pelajaran akademik, anak tunagrahita dapat dikembangkan secara optimal, mereka memerlukan layanan khusus. Dampak dari ketunagarhitaan menyebabkan mereka mengalami gangguan dalam bidang akademik, menyesuaikan diri dengan lingkungan mengalami ganguan bicara, bahasa serta emosi, anak tipe tunagrahita ringan tingkat keecerdasannya sama dengan anak berusia 9-12 tahun. Tunagrahita Sedang (IQ 3050) adalah mereka yang tidak mampu mempelajari pelajaran akademik, perkembangan bahasa sedikit terbatas, hanya bisa berkomunikasi dengan beberapa kata saja, mengenal angka tanpa pengertian, dapat dilatih bersosialisasi namun hanya mengetahui orang terdekatnya saja, mampu mengenali bahaya, tingkat kescerdasan setara anak usia 6 tahun. Tunagrahita Berat (IQ nya kurang dari 30) adalah mereka yang tidak bisa merawat atau mengurus diri sendiri, selalu tergantung pada orang lain, tidak mengenali bahaya, bisa bersosial hanya dengan lingkungan yang sangat terbatas tingkat kecerdasannya setara dengan anak usia 4 tahun.

(Mulyono n.d.) mengungkapkan bahwa bahan ajar merupakan seperangkat informasi yang harus diserap peserta didik melalui pembelajaran yang menyenangkan. Secara umum bahan ajar dapat dibedakan ke dalam bahan ajar cetak dan noncetak. Sedangkan media pembelajaran multimedia inetarktif adalah menurut (Pebody et al. 2012) berpendapat bahwa "multimedia merujuk pada berbagai kombinasi dari dua atau lebih format media yang terintegrasi kedalam bentuk informasi atau program instruksi." Karakteristik belajar anak tunagrahita salah satunya adalah sukar berfikir dan cenderung belajar melalui pengalaman secara kongkret, darisitu penggunaan media pembelajaran multimedia interaktif sangat membantu mereka dalam menerima materri pembelajaran, juga untuk memudahkan guru dalam pengajarannya, misal kita akan memberi materi tentang mengenal macam-macam hewan apakah kita harus membawa hewan trsebut untuk masuk kedalam kelas, tentunya tidak, dengan multiedia interaktif yang kita kembangkan dapat memudahkan siswa berkebuuhan tunagrahita untuk memahami materi yang akan kita sajikan. Menurut Meimulyani \& Caryoto (2013:80) berpendapat bahwa anak tunagrahita mempunyai keterlambatan daya tangkap dan berpikirnya, dan membutuhkan penggunaan media pembelajaran dalam bentuk yang konkrit dan sangat menarik perhatian karena anak tunaghrahita cepat bosan dan mudah beralih perhatianya. Sehingga perlu adanya media yangkonkrit, menarik, serta mudah dipahami oleh anak tunagrahita. Salah satunya adalah multimedia interaktif berupa video animasi atau foto. Dengan meyajikan media berupa video dan foto yang menarik perhatian, materi yang disampaikan akan cepat ditangkap oleh anak tunagrahita. Dalam penggunaan media pembelajaran multimedia interaktif sangat membentu keberlangsungan pembelajaran bagi anak tunagrahita. Menurut hasil penelitian beberapa jurnal, siswa yang menderita tuna grahita ringan dapat terbantu dngan adanya media pembelajaran interaktif, keberhasilan media interaktifnya dapat dilihat dari segi 
designnya, dan penggunaan multimedia interaktifnya dapat meningkatkan keaktifan pemahaman siswanya.

\section{Tunagrahita}

Pada diri tiap anak ada kemampuan atau potensi yang unik bagi dirinya. Dan hakhak anak (child right) yang menyatakan bahwa semua anak memiliki hak dan kewajiban yang sama untuk hidup dan berkembang secara penuh sesuai dengan potensi yang dimilikinya. Salah satunya pada anak berkebutuhan khusus adalah yang termasuk anak yang mengalami hambatan dalam perkembangan perilakunya. Perilaku anak-anak ini tidak berkembang seperti pada anak yang normal. Istilah anak berkelainan mental subnormal dapat disebut juga dengan keterbelakangan mental, lemah ingatan (feebleminded), tunagrahita. Semua makna di atas menunjuk kepada seseorang yang memiliki kecerdasan mental di bawah normal (Efendi, 2006). Pada umumnya anak berkebutuhan khusus ini biasa disebut anak tunagrahita. Anak tunagrahita adalah anak yang mengalami hambatan dalam perkembangan mental dan intelektual sehingga juga berdampak pada perkembangan kognitif dan perilakunya, seperti tidak mampu memusatkan pikiran, emosi tidak stabil, suka menyendiri dan pendiam.gangguan mental anak tunagrahita ini disebabkan karena tingkat kecerdasannya yang rendah, juga memiliki kekurangan dalam beradaptasi dengan lingkungannya, mereka hanya akan mengenal keluarga terdekat mereka saja, seperti ayah, ibu dan saudara kandungnya, keterbelakangan lain yang menimpa anak tunagrahita salah satunya adalah keterbelakangan komunikasi, akademik dan kecepatan berpikirnya, anak tunagrahita ini memiliki IQ dibawah angka 70. Hingga saat ini penanganan anak tunagrahita tidak dapat dipahami secara mendalam oleh para orangtua dan lembaga atau sekolah khusus anak tunagrahita. Salah satunya adalah penyediaan sarana dan prasarana ruang belajar sebagai proses belajar-mengajar. Ruang belajar ini penting dan perlu diperhatikan demi perkembangan anak tunagrahita.(Yosiani 2014).

\section{Karakteristik Tunagrahita}

Salah satu ciri-ciri anak tunagrahita memiliki keterbatasan dalam penguasaan bahasa. Pusat pengolahan perbendaharaan kata mereka yang kurang berfungsi sebagaimana mestinya".Karena alasan tersebut mereka membutuhkan kata-kata konkret yang sering didengarnya.Pada umumnya mereka mengalami kesulitan dalam menerima informasi, baik dalam pelaksanaan belajar mengajar maupun dalam kehidupan sehari-hari. Hambatanhambatan ini disebabkan oleh daya berfikir abstrak yang rendah.(Ramawati, Allenidekania, and Besral, 2012). Anak tuna grahita juga kesusahan dalam beradaptasi dengan lingkungan baru atau disebut interkasi sosial. Interaksi sosial merupakan hubungan sosial yang dinamis, menyangkut hubungan antara individu, antara kelompok, maupun antara individu dengan kelompok. Interaksi terjadi apabila dapat terjadi apabila memiliki dua syarat yaitu adanya kontak sosial dan komunikasi (Soekanto and Abdullah, 1980). Selain daripada itu anak tunagrahita juga mengalami masalah dalam hal penyesuaian diri yaitu kesulitan dalam berhubungan dengan kelompok maupun individu di sekitarnya dan hal ini dipengaruhi akibat kecerdasan yang di bawah rata-rata.

\section{Tingkatan Tunagrahita}

Anak berkebutuhan khusus tunagrahita dibagi menjadi empat tingkatan, tiap tingkatan memiliki perawatan khusus yang berbeda - beda sesuai tingakatan dan kebutuhan masing- masing, tingkatan yang pertama adalah tunagrahita ringan yaitu anak tunagrahita yang kecredasan kognitifnya mencapai anak usia 7 sampai 12 tahun, mereka mampu hidup dengan cara mereka sendiri, anak tuna grahita ringan cukup dapat berkomunikasi dengan 
baik, mereka juga cukup mampu memberikan sedikit penjelasan, yang paling terlihat dari tanda-tanda anak tunagrahita ringan adalah perkembangan mereka, semakin bertambahnya umur mereka keterlambatan perkembangan mereka akan semakin terlihat, biasanya tanda keterlambatan mereka baru terlihat saat mereka berusia 6 tahun, ketika mereka memasuki bangku sekolah, anak tunagrahita akan kesusahan memahami hal-hal yang ada di bangku sekolah. Anak tuna grahita ringan ini biasanya hanya asik dengan dirinya sendiri atau bisa disebut egosentris, anak bertipe ini sangat gampang dipengaruhi oleh orang lain, karena dia belum bisa membela dirinya dan belum bisa meindungi dirinya sendiri, anak tuna grahita ini juga sadar bahwa dirinya berbeda, dia beranggapan bahwa waktu berjalan sangat cepat daripada orang lain, mereka akan merasa gelisah dan panik ketika dia tidak diberi waktu untuk memahami dunia sekitarnya, namun anak tunagrahita ringan masih bisa didik untuk dapat beradaptasi dengan ingkungan sekitar jika diberi dukungan penuh dari orangtua, dokter atau spesialisnya.

Yang kedua ada tingkatan tunagrahita sedang, yaitu mereka yang dapat mencapai usia perkembangan kognitifnya anak umur 4 sampai 7 tahun, biasanya mereka mampu mengerti apa yang mereka inginkan, tapi lebih banyak masih membutuhkan bantuan, mereka juga masih bisa merawat dirinya dengan sedikit, misalnya memakai baju sendiri, makan dan mengambil minum sendiri bahkan mereka juga masih bisa pergi ke toilet sendiri, namun dalam melakukan aktifitas tersebut mereka masih tetap memerlukan bimbingan. Anak tunagrahita sedang masih bisa mengucapkan keinginannya, namun dengan kosakata yang terbatas, mereka juga kadang masih kesusasan atauy kesulitan memahamui maksud perkataan orang lain, namun demikian kita masih bisa berkomunikasi sederhana dengan anak tunagrahita sedang. Kemampuan motorik anak tunagrahita sedang juga tampak lamban karena salah satu ciri anak tunagrahita ringan adalah mereka sangat sedikit menggerakan badan mereka. Anak tunagrahita tipe sedang ini mampu menyebutkan macam- macam perasaan, seperti marah,senang, sedih dan lainnya, namun mereka masih beum bisa mengontrol emosi tersebut. Anak tunagrahita sedang akan selalu membutuhkan dukiungan atau perhatian yang cukup ekstra untuk mengawasi perkembangan dan aktifitas yang dilakukan, ketika sudah beranjak dewasa anak tuna grahita ringan ini akan tetap membuthkan dukungan dan pantauan dari orang terdekat,.

Yang ketiga adalah tunagrahita berat, yaitu mereka yang usia perkembangan kognitifnya pada anak umur 2 sampai 4 tahun. Mereka sangat membutuhkan bimbingan dalam setiap aspek kehidupannya, anak tunagrahita ringan ini dalah anak yang sangat pasif dari segi motorik juga sangat pasif dan sangat membutuhkan banyak rangsangan agar mereka termootivasi melakukan sesuatu, tunagrahita ini masih bisa melakukan aktifitas ringan seperti mengambil barang yang ada didepannya, memilih salah satu benda, atau menghabiskan makanannya, dalam berkomunikasi tunagrahita berat sangat minim kosa kata untuk berkomunikasi dengan anak tunagrahita berat hanya bisa dengan sapaan hanya dapat dilakukan dengan beberapa kata saja, isyarat -isyarat atau bunyi- bunyian, namun mereka akan membalas sapaan hanya dari orang terdekat yang dikenal saja, jika ada orang baru yang ingin brinteraksi dengan anak tunagrahita berat akan sangat susah mendapatkan respon karena mereka tidak mengenali. Anak tunagrahita berat juga tidak bisa mengatur emosi mereka, mereka sangat mudah merasakan ketegangan dalam dirinya, emosi mereka sangat tidak stabil, ekstrem, meledak-ledak dan tidak bisa dikendalikan, saat mereka dalam keadaan senang seketika mereka bisa berubah menjadi sedih dengan tiba-tiba dan tanpa sebab apapun, tidak pernah merasa dalam kondisi yang seimbang dalam dirinya, mereka tidak tahu bagaimana cara mengerem perasaan mereka, oleh karena itu tunagrahita berat 
cenderung sering melakukan hal yang tidak baik dalam lingkungannya, salah satu cirinya alah mereka ssering melakukan gerakan yang berulang-ulang, seperti menggoyangkan tubuhnya secara terus menerus, anak- anak ini juga sering sekali mengalami gangguan pada panca indera mereka, seperti penglihatan, pendengaran maupun anggota motoriknya, mereka tidak mampu menggunakan tangan dan kaki mereka secara terarah, sering kali mereka tidak mampu emengkondisikan tubuh mereka, tunagrahita tipe berat ini cenderung lemah, mereka akan sering mengalami keluhan fisik, anak tunagrahita tipe berat sangat membutuhkan lingkungan yang sangat aman menurut mereka dan memerlukan bimbingan yang konsisten. Yang terakhir adalah anak tunagrahita sangat berat, mereka dapat memperoleh perkembangan kognitif anak umur 2 tahun, tunagrahita berat mereka hidup dalam dunia mereka sendiri, mereka menutup diri dari lingkungan sekitar. Mereka hampir tidak bisa hidup secara mandiri, semua kebutuhannya harus selalu memerlukan bantuan, mereka harus terus dilayani karena motorik dan otak mereka sudah tidak dapat bersinergi, hal-hal seperti makan, minum, mandi, meeleepas baju atau mengambil barang mereka tidak bisa melakukannya dengan mandiri, anak tunagrahita ini cenderung selalu terbaring di tempat tidur dan sering merasa sakit dan kesehatannya sangat lemah, biasanya anak tunagrahita tipe ini memiliki masalah kesehatan seperti epilepsi dan susah makan dan minum. Mereka juga hampir tidak bisa berkomunikasi dengan baik, bahkan cenderung tidak dapat berkomunikasi dengan menggunakan kata-kata mereka juga jarang menunjukan emosinya, karena mereka tidak bisa mengetahui bagaimana itu senang, sedih bahagia dan lain-lain, karena tunagrahita sangat berat ini sangat pasif dalam segala hal. Setelah memahami tipe macam tunagrahita, tiap tingkatan tunagrahita memiliki beda peawatan, dan memiliki macam-macam kebutuhan yang berbeda sesuai tingkatannya, baik dalam perawatan, cara mereka menerima informasi atau dalam penyampaian materi, yang akan kita bahas adalah penggunaan multimedia interaktif untuk tipe tunagrahita ringan.

\section{Multimedia Interaktif}

Anak tunagrahita membutuhkan media pembe;ajaran berbasis IT untuk meningkatkan kemampuan kognitifnya. Dalam meningkatkan kemampuan kognitif pada anak tunagrahita dapat menggunakan berbagai metode dan media yang menarik minat anak untuk belajar (Purwaningrum, 2017) salah satunya yaitu multimedia interaktif. (Setyaningrum, 2011) Pembelajaran yang memakai multimedia interaktif didalamnya terdapat unsur audio dan visual yang dapat melatih daya poikir dan daya ingat anak, terutama untuk anak tunagrahita ringan, penggunaan multimedia interaktif adalah salah satu pilihan yang cocok, karena materi yang disajikan sudah konkrit tidak konvensional. (Husein, Herayanti, and Gunawan, 2017) Multimedia Interaktif adalah suatu multimedia yang dilengkapi dengan alat pengontrol yang dapat dioperasikan oleh pengguna, sehingga pengguna dapat memilih apa yang dikehendaki untuk proses selanjutnya.(Satya Purwanata and Rianto, 2019) Multimedia interaktif adalah pembelajaran yang meliputi video, audio dan gambar bisa juga memakai animasi, pembelajaran dengan menggunakan multimedia interaktif dapat meningkatkan kualitas pembelajaran karena materi dan penyajian pembelajarannya sangat menarik perhatian peserta disik, dan juga sangat relevan untuk mempersingkat pengajaran karena materi yang disajikan akan cepat tersampaikan dari paada pembelajaran konvensional, siswa juga akan lebih mudah memahami dengan memakai pembelajaran multimedia interaktif.

Pengggunaan multimedia interaktif sangatlah beragam salah satunya adalah dengan adobe flash, "Adobe Flash merupakan program animasi yang juga mendukung pemrograman dengan Action Script, program ini tepat digunakan untuk mengembangkan 
MPI (Multimedia Pembelajaran Interaktif) karena mendukung animasi, gambar, image, teks \& pemrograman" (Nurtantio, P \& Syarif, 2013). Suatu media pembelajaran yang dapat menarik perhatian siswa dan meningkatkan motivasi siswa pada saat proses belajar mengajar berlangsung termasuk pada saat pembelajaran keterampilan, salah satu media yang dapat digunakan adalah media pembelajaran video tutorial. Penggunaan media pembelajaran video tutorial ini akan sangatmembantu dan mempermudah siswa maupun guru, terutama dalam pembelajaran keterampilan, karena media video tutorial ini memberikan penanyangan materi secara bertahap dan beruntun serta dapat disesuaikan dengan kemampuan siswa tunagrahita sehingga akan lebih memudahkan siswa tunagrahita dalam menyerap materi yang diajarkan oleh guru (Putri, 2012). Dengan penelitian tentang multimedia interaktif menemukan bahwa peningkatan penguasaan konsep mahasiswa yang mengikuti pembelajaran menggunakan kelompok belajar berciri kooperatif berbantuan multimedia interaktif secara signifikan lebih tinggi dibandingkan dengan mahasiswa yang mengikuti yang mengikuti pembelajaran konvensional, Sehingga media tersebut diharapkan sesuai dengan karakter anak tunagrahita, materi yang mudah dipahami dan bersifat konkrit (Putriani, 2017). (Horner et al., 2005) Metode yang digunakan pada beberapa penelitian ini adalah metode eksperimen dengan subjek tunggal atau Single Subject Research (SSR) yaitu suatu metode yang bertujuan untuk mengetahui ada tidaknya akibat dari suatu perlakuan yang diberikan. SSR mengacu pada strategi penelitian yang dikembangkan untuk mendokumentasikan perubahan tentang tingkah laku subjek secara individu. Hal ini memungkinkan untuk memperlihatkan hubungan fungsional antara perlakuan dan perubahan tingkah laku. Pola desain eksperimen subjek tunggal yang dipakai dalam penelitian ini adalah desain A-B-A'(Resmanda, 2018). Dimana A (Baseline 1) adalah lambang dari data garis datar. Yang merupakan suatu kondisi awal kemampuan subjek dalam membaca permulaan sebelum diberi perlakuan atau intervensi. B (Intervensi) adalah untuk data perlakuan atau intervensi, kondisi kemampuan subjek dalam membaca permulaan selama intervensi. Pada tahap ini subjek diberikan intervensi dengan menggunakan multimedia interaktif cerdas belajar baca secara berulang-ulang. A' Baseline 2) merupakan pengulangan kondisi baseline sebagai evaluasi setelah intervensi diberikan. Didalam disain A-B-A' ini terdapat tiga fase yang memiliki tujuan untuk mempelajari besarnya pengaruh dari suatu perlakuan yang diberikan kepada individu dengan membandingkan kondisi baseline sebelum dan sesudah diberikan suatu perlakuan atau intervensi. Dalam hal ini ingin diketahui seberapa besar pengaruh penggunaan multimedia interaktif cerdas belajar baca dalam meningkatkan kemampuan membacapermulaan padaanak tunagrahita ringan. $\mathrm{A}=$ Baseline 1 , baseline 1 merupakan kondisi awal kemampuan anak dalam membaca permulaan sebelum diberikan perlakuan atau intervensi. Fase baseline ini akan dilakukan sampai data yang diperoleh stabil. $\mathrm{B}=$ Intervensi, intervensi adalah kondisi kemampuan anak dalam membaca permulaan selama memperoleh perlakuan. Fase intervensi ini akan dilakukan sampai data yang diperoleh stabil dengan menggunakan multimedia interaktif cerdas belajar baca. $\mathrm{A}^{\prime}=$ Baseline 2 , baseline 2 merupakan pengulangan kondisi baseline sebagai evaluasi dari intervensi yang telah diberikan yang bertujuan untuk melihat apakah intervensi yang dilakukan memberikan pengaruh terhadap kemampuan atau keterampilan anak dalam membaca permulaan. Fase baseline kedua ini akan dilakukan sampai data yang diperoleh. Dalam pembelajaran didalam kelas, anak tunagrahita sangatlah lambat daya tangkapnya, penggunaan media pembelajaran dalam bentuk konkrit sangat menarik karena anak tunaghrahita cepat bosan dan mudah beralih perhatianya. Sehingga perlu adanya media yang menarik, konkrit dan 
mudah dipahami oleh anak tunagrahita. Salah satunya adalah multimedia interaktif berbasis Adobe Flash.(Fitri, 2017). (Jauhari, 2009) mengemukakan "Multimedia Interaktif adalah suatu multimedia yang dilengkapi dengan alat pengontrol yang dapat dioperasikan oleh pengguna, sehingga pengguna dapat memilih apa yang dikehendaki untuk proses selanjutnya". "Penggunaan multimedia interaktif dapat membuat proses belajar lebih menarik, lebih interaktif, jumlah waktu mengajar dapat dikurang, kualitas belajar siswa dapat ditingkatkan dan proses belajar mengajar dapat dilakukan dimana dan kapan saja, serta sikap belajar siswa dapat ditingkatkan" (Praheto et al., 2017)Penggunaan multimedia interaktif sangatlah beraneka ragam salah satunya menggunakan software/ aplikasi Adobe Flash. "Adobe Flash merupakan program animasi yang juga mendukung pemrograman dengan Action Script, program ini tepat digunakan untuk mengembangkan MPI (Multimedia Pembelajaran Interaktif) karena mendukung animasi, gambar, image, teks \& pemrograman" (Azaria and Panjaitan n.d.). Sehingga media tersebut diharapkan sesuai dengan karakter anak tunagrahita, materi yang mudah dipahami dan bersifat konkrit. Berdasarkan masalah-masalah tersebut maka menjadi sangat penting untuk dilaksanakansuatu penelitian dengan menggunakan multimedia interaktif berbasis Adobe Flash terhadap peningkatan prestasi belajar.

\section{Kesimpulan dan Saran}

Berdasarkan hasil dari beberapa artikel hasil penelitian penelitian maka dapat disimpulkan bahwa penggunaan multimedia interaktif yang meliputi audio dan visual sangat berpengaruh dan membantu keberhasilan penyampaian materi oleh tenaga pendidik didalam kelas, karena dapat menciptakan pembelajaran yang menyenangkan, memotivasi, meningkatkan antusias anak dalam belajar, serta meningkatkan daya ingat anak. karena materi pembelajaran disajikan dalam bentuk yang konkrit dan dikemas dalam bentuk yang semakin menarikperhatian peserta didik, dan dapat disimpulkan juga bahwa penggunaan multimedia interaktif berpengaruh signifikan terhadap peningkatan prestasi belajar anak tunagrahita ringan.

\section{Daftar Rujukan}

Azaria, Cut Nabila, and Ruqiah Ganda Putri Panjaitan. n.d. Kelayakan Multimedia Interaktif Berbasis Adobe Flash Pada Sub Materi Gangguan Kesehatan Reproduksi. Jurnal Pendidikan dan Pembelajaran Khatulistiwa 6(4).

Basuni, Muhamad. (2012). Pembelajaran Bina Diri Pada Anak Tunagrahita Ringan. JPK (Jurnal Pendidikan Khusus) 9(1).

Efendi, M. (2006). Pengantar Psikopedagogik Anak Berkelainan. JKP(Jurnal Pendidikan Khusus) 1 (4).

Fitri, Eka. (2017). Rancang Bangun Media Pembelajaran Untuk Anak Tunagrahita Berbasis Multimedia (Studi Kasus: SLB ABCD Kuncup Mas Banyumas).

Horner, Robert H., Edward G. Carr, James Halle, Gail McGee, Samuel Odom, and Mark Wolery. (2005). The Use of Single-Subject Research to Identify Evidence-Based Practice in Special Education. Exceptional Children 71(2):165-79.

Husein, Sadam, Lovy Herayanti, and Gunawan Gunawan. (2017). Pengaruh Penggunaan Multimedia Interaktif Terhadap Penguasaan Konsep Dan Keterampilan Berpikir Kritis Siswa Pada Materi Suhu Dan Kalor. Jurnal Pendidikan Fisika dan Teknologi 1(3):221-25.

Jauhari, Jaidan. (2009). Studi Terhadap Penggunaan Multimedia Interaktif dalam Pembelajaran MIPA Di Indonesia. dalam Prosiding Seminar Nasional Penelitian, 
Pendidikan dan Penerapan MIPA. UNY Yogyakarta, tanggal. Vol. 16.

Mulyono, Dwi Budi. n.d. Model Bahan Ajar Bahasa Dan Sastra Indonesia Yang Ideal dan Inovatif. Edukasi Kultura: Jurnal Bahasa, Sastra dan Budaya 1(1).

Nurtantio, P \& Syarif, M. (2013). Kreasikan Animasimu Dengan Adobe Flash.

Pebody, R. G., M. A. Chand, H. L. Thomas, H. K. Green, N. L. Boddington, C. Carvalho, C. S. Brown, S. R. Anderson, C. Rooney, and E. Crawley-Boevey. (2012). The United Kingdom Public Health Response to an Imported Laboratory Confirmed Case of a Novel Coronavirus in September 2012. Eurosurveillance 17(40):20292.

Praheto, Biya Ebi, Andayani Andayani, Muhammad Rohmadi, and Nugraheni Eko Wardani. (2017). Peran Multimedia Interaktif Dalam Pembelajaran Keterampilan Berbahasa Indonesia di PGSD. dalam Proceedings Education and Language International Conference. Vol. 1.

Purwaningrum, Siska Putri. (2017). Implementasi Metode Eksperimen Pada Pembelajaran IPA di Kelas V SD N 2 Kemiri Sumpiuh Banyumas.

Putri, Nadya. (2012). Efektifitas Penggunaan Media Video Untuk Meningkatkan Pengenalan Alat Musik Daerah Pada Pembelajaran IPS Bagi Anak Tunagrahita Ringan Di SDLB 20 Kota Solok. Jurnal Ilmiah Pendidikan Khusus 1(2):318-28.

Putriani, Gigih. (2017). Peningkatan Upaya Pembelajaran Bina Diri Menggosok Gigi Melalui Media Video Animasi Pada Anak Tunagrahita Kategori Sedang Kelas IV Sdlb di SLB Negeri Pembina Yogyakarta. Widia Ortodidaktika 6(2):208-19.

Ramawati, Dian, Allenidekania Allenidekania, and Besral Besral. (2012). Kemampuan Perawatan Diri Anak Tuna Grahita Berdasarkan Faktor Eksternal dan Internal Anak. Jurnal Keperawatan Indonesia 15(2):89-96.

Rejoko, Bimo. N.D. Media Pembelajaran Interaktif Ciri Khas Makhluk Hidup Manusia Untuk Kelas 5 SDLB Anak Tuna Grahita Ringan.

Resmanda, Rizqia Nabila. (2018). Pengaruh Modifikasi Pembelajaran Pendidikan Jasmani Terhadap Peningkatan Partisipasi Siswa Berkebutuhan Khusus di Kelas Inklusi: Studi Eksperimen Single Subject Research Dengan Desain ABA Pada Anak Tunadaksa di Kota Sukabumi.

Satya Purwanata, Lalu, and E. D. Y. Rianto. (2019). Penerapan Media Video Berbasis IT Terhadap Kemampuan Membaca Kalimat Sederhana Anak Tunagrahita Ringan Kelas III. Jurnal Pendidikan Khusus 12(3).

Setyaningrum, Anjar. (2011). Pengaruh Multimedia Interaktif Tipe True or False dalam Pembelajaran Terhadap Prestasi Belajar Matematika Anak Tunagrahita Kelas IV di SLB ABCD YSD Polokarto Tahun Pelajaran 2010/2011.

Soekanto, Soerjono, and Mustafa Abdullah. (1980). Sosiologi Hukum Dalam Masyarakat. Rajawali.

Widiansyah, Arindra Trisna. (2013). Pengembangan Multimedia Pembelajaran Interaktif Kompetensi Penggolongan Hewan Berdasarkan Jenis Makanannya Pada Siswa Tunagrahita Ringan Kelas VII Di Sekolah Menengah Pertama Luar Biasa Kemala Bhayangkari 1 Trenggalek.

Yosiani, Novita. (2014). Relasi Karakteristik Anak Tunagrahita Dengan Pola Tata Ruang Belajar di Sekolah Luar Biasa. E-Journal Graduate Unpar 1(2):111-24. 